\title{
Why and how you should learn to do the Ross Procedure in 2020
}

\author{
Tirone E. David \\ Division of Cardiac Surgery, Toronto General Hospital, University of Toronto, Toronto, Ontario, Canada \\ Correspondence to: Tirone E. David, MD. 200 Elizabeth St. 4N453, Toronto, Ontario M5G 2C4, Canada. Email: tirone.david@uhn.ca.
}

Submitted Jun 28, 2020. Accepted for publication Jul 30, 2020.

doi: 10.21037/acs-2020-rp-10

View this article at: http://dx.doi.org/10.21037/acs-2020-rp-10

The Ross procedure is as close to a perfect aortic valve substitute in selected patients as is currently possible, and when correctly performed, the long-term outcomes are second to no other type of aortic valve replacement (AVR) (1-3). This operation was first described more than one-half century ago, but most cardiac surgeons have never used it, likely due to its complexity compared to AVR with manmade heart valves. As with any complex operation there is a learning curve, the steepness of which is dependent on the surgeon's technical skills, knowledge of semilunar valve functional anatomy and procedural frequency. Additionally, an experienced surgeon is required as a mentor through the first five to ten Ross procedures.

The Ross procedure involves transferring the pulmonary valve into the aortic position. This is technically demanding and the surgeon must also correct the differences in geometry of the aortic root to match the geometry of the pulmonary valve during surgery (4-6). In healthy children and young adults, the pulmonary valve sinotubular junction (STJ) is 2 to $3 \mathrm{~mm}$ larger than the aortic valve STJ, but this relationship is often altered in patients with aortic valve disease. The annulus of the semilunar valves is slightly larger than its STJ. The geometry of the pulmonary valve must be maintained when transferred to the aortic position, regardless of the technique used for implantation. Thus, not only must the transverse diameters of the pulmonary annulus and STJ be maintained but also the crescent shape of each cusp insertion. This may be difficult to do because most candidates have bicuspid aortic valve (BAV) disease which frequently have an abnormal aortic annulus and STJ. In addition, the surgeon must ensure that the level of the pulmonary annulus coincides with that of the aortic annulus, which is not always possible because of the abnormal anatomy of the aortic annulus.
Whenever possible, the pulmonary annulus should be placed lower in relation to the aortic annulus in most of the circumference of the left ventricular outflow tract (LVOT). The right ventricular muscle in the sub-commissural triangles of the pulmonary root should be resected because it will die and be replaced by fibrous tissue. Thus, it is extremely important that the sub-commissural areas be externally supported by the native aorto-ventricular junction or aortic root tissue to prevent dilatation of the pulmonary annulus during healing. The technique of sub-coronary implantation is the best approach for this operation if the geometries of both roots are similar. In my experience, this is the exception, not the rule. The aortic root inclusion technique is probably the second best, and can be performed in practically all patients if the surgeon can detach and mobilize the right coronary artery, which often does not align correctly with a normal pulmonary root. Finally, the free-standing root is an acceptable approach as long as sub-commissural triangles of the pulmonary valve are externally supported by LVOT or aortic root tissues. I do not believe the proximal anastomosis should be buttressed with a strip of Teflon felt. This is unnecessary if the pulmonary annulus is at the same level or below the aortic annulus and may adversely affect long-term durability of the pulmonary autograft. The STJ of the pulmonary root must be maintained upon completion, regardless of the technique used for implantation in the aortic position. This may require reduction in the ascending aorta diameter, particularly when the aortic root replacement technique is used.

Some surgeons mount the pulmonary autograft inside a Dacron graft with sinuses of Valsalva before implantation in the aortic position. I remain skeptical of this approach and doubt the pulmonary autograft will function as well as 
the above described techniques. We will have to wait for this approach to pass the test of time before abandoning the classical approaches of implanting the pulmonary valve in the aortic position.

Patients with BAV may have an aortic annulus larger than the pulmonary annulus, hence a reduction annuloplasty is necessary before transferring the pulmonary autograft to the aortic position. Patients with an incompetent BAV may have a very large aortic annulus (i.e., $>30 \mathrm{~mm}$ ) and are questionable candidates even if the aortic root inclusion technique is used, as annular dilatation may be a marker of more serious connective tissue disease. Some patients with incompetent BAV have large dilated pulmonary roots. The significance of this finding is unclear, but I have been reluctant to perform the Ross procedure in patients with a pulmonary STJ greater than $30 \mathrm{~mm}$, regardless of their body surface area (BSA). Although the diameters of the aortic and pulmonary annuluses relate to the patients' BSA, this relationship flattens in individuals with BSAs larger than $2 \mathrm{~m}^{2}$. The normal aortic annulus is relatively small and seldom exceeds $25 \mathrm{~mm}$, even in large individuals (7).

The normal pulmonary valve has adaptive properties to tolerate systemic pressure which is why patients with severe pulmonary hypertension often have a normally functioning pulmonary valve. This adaptive property is probably maintained when the pulmonary valve is transferred to the aortic position but the long-term effect of severing all its connections with the right ventricle remains unclear. The loss of native blood supply and innervation may adversely affect its adaptive properties. From my experience with the Ross procedure and other operations that rely on adaptive properties of tissues and organs, I believe these adaptive properties diminish in older humans. If correct, children and young adults are likely to do better than older patients after the Ross procedure.

Carefully selecting patients for the Ross procedure during the first three decades of my practice has yielded gratifying results, with over $80 \%$ of patients free from any Ross-related reintervention or hemodynamically important aortic insufficiency at twenty years. I have become more liberal in the use of this operation and have included patients with ascending aorta or aortic root aneurysm associated with BAV, and aortic insufficiency with grossly dilated aortic annulus. My reasoning is that most young patients do not want to be on lifelong warfarin, a requirement for a mechanical aortic valve. Time and continued surveillance of these patients will show if this was the correct move. Large series of the Ross procedure with echocardiographic surveillance of valve function are needed to better define the benefits and shortcomings of this operation. I doubt a prospective randomized clinical trial on the Ross procedure versus a mechanical aortic valve will ever be conducted because of the duration of follow-up needed to demonstrate differences in survival and clinical outcomes.

\section{Acknowledgments}

Funding: None.

\section{Footnote}

Conflicts of Interest: The author has no conflicts of interest to declare.

Open Access Statement: This is an Open Access article distributed in accordance with the Creative Commons Attribution-NonCommercial-NoDerivs 4.0 International License (CC BY-NC-ND 4.0), which permits the noncommercial replication and distribution of the article with the strict proviso that no changes or edits are made and the original work is properly cited (including links to both the formal publication through the relevant DOI and the license). See: https://creativecommons.org/licenses/by-nc-nd/4.0/.

\section{References}

1. Martin E, Mohammadi S, Jacques F, et al. Outcomes following the Ross Procedure in adults: A 25-year longitudinal study. J Am Coll Cardiol 2017;70:1890-9.

2. Sievers H-H, Stierlel U, Petersen M, et al. Valve performance classification in 630 subcoronary Ross patients over 22 years. J Thorac Cardiovasc Surg 2018;156:79-86.

3. David TE, Ouzounian M, David CM, et al. Late results of the Ross procedure. J Thorac Cardiovasc Surg 2019;157:201-8.

4. Swanson M, Clark RE. Dimensions and geometric relationships of the human aortic valve as a function of pressure. Circ Res 1974;35:871-2.

5. Kunzelman KS, Grande KJ, David TE, et al. Aortic root and valve relationships. Impact on surgical repair. J Thorac 
Cardiovasc Surg 1994;107:162-70.

6. David TE, Omran A, Ivanov J, et al. Dilation of the pulmonary autograft after the Ross procedure. J Thorac Cardiovasc Surg 2000;119:210-20.

Cite this article as: David TE. Why and how you should learn to do the Ross Procedure in 2020. Ann Cardiothorac Surg 2021;10(4):518-520. doi: 10.21037/acs-2020-rp-10
7. Capps SB, Elkins RC, Fronk DM. Body surface area as a predictor of aortic and pulmonary valve diameter. J Thorac Cardiovasc Surg 2000;119:975-82. 